\title{
CRIMINAL LEGAL PROTECTION OF PERSON'S HEALTH AS A CONSTITUTIONAL GUARANTEE OF THE PROVISION OF HUMAN RIGHTS AND FREEDOMS
}

\section{Katerynchuk K. V.}

\section{INTRODUCTION}

The Constitution of Ukraine proclaims not only life but health as well (Article 3) as the highest social value and impose obligations on the state to provide their protection (Article 49) by all legal means (civil law, labor law, administrative law etc. $)^{1}$. The Constitution of Ukraine is the Basic Law of our state and all laws without exception as well as all normativelegal act are based on it, the Criminal Code of Ukraine is included ${ }^{2}$ (hereinafter referred to as the $\mathrm{CC}$ of Ukraine). For that reason Part 1 Article 3 of the CC of Ukraine states the provision that the CC of Ukraine is based on the Constitution of Ukraine and widely recognized principles and norms of international law.

As one of the most preferential direction of state activity according to the Law of Ukraine "The Basics of Legislation of Ukraine on Health Protection", , health protection is a system of measures carried out by state authorities and self-government bodies, their officials, health protection institutions, physical persons - entrepreneur, registered under the established procedure and obtained a license on economic activity on medical practice, medical and pharmaceutical employees, public associations and citizens with the aim of preservation and renewal of physiological and psychological functions, optimal capability for work and social activity of a person at maximum biologically possible individual life expectancy (Clause 8 Part 1 Article 3). The goal stated in the Law, in our opinion, should be specified in the part of preservation and rehabilitation of physiological and renewal of mental activity.

\footnotetext{
${ }^{1}$ Конституція України: Закон від 28.06.1996 р. № 254к/96-ВР. Дата оновлення: 21.02.2019 p. URL: http://zakon2.rada.gov.ua/laws/show/254к/96-вр.

${ }^{2}$ Кримінальний кодекс України: Закон від 05.04.2001 р. № 2341-III. Дата оновлення: 26.02.2019 p. URL: http://zakon4.rada.gov.ua/laws/show/2341-14.

Основи законодавства України про охорону здоров'я: Закон України від 19.11.1992 p. № 2801-XII. Дата оновлення 01.01.2019 p. URL: http://zakon5.rada.gov.ua/laws/show/2801-12.
} 
In Ukraine, at the state level, a complete organizational and legal system is approved and is functioning. Formation and provision of health care policy is imposed on the state, the main functions of which are the following:

1) Control and supervision over observance of the legislation on health care through specially authorized executive bodies;

2) Prevention of infectious diseases, dangerous for people.

The formation of public health policy is carried out by the Verkhovna Rada of Ukraine, by consolidating constitutional and legislative principles of health care, defining its goals, main tasks, directions, principles and priorities, establishing standards and amounts of budget financing, creating a system of appropriate credit- financial, tax, customs and other regulators, approval of national health programs (Article 13). In turn, the Cabinet of Ministers of Ukraine organizes development and implementation of state specialized programs ${ }^{4}$, creates economic, legal and organizational mechanisms stimulating effective activity in heal care field, provides the development of chain of health care institutions, concludes international treaties and coordinates international cooperation on health care issues, as well as executes other powers within its competence, vested on executive bodies in the field of health care (Article 14). Health care authorities (the central body of executive power and other central bodies of executive power) implement state policy in the field of health care.

The Law of Ukraine "On Amendments to Certain Legislative Acts of Ukraine on the Improvement of Legislation Regarding Activities of Health Care Institutions" 5 provides definition of health care institution this is a legal entity of any form of ownership and organizational-legal form or its separated unit providing medical care to population on the

\footnotetext{
${ }^{4}$ Катеринчук К. В. Державні програми, як основа запобігання злочинних посягань на здоров'я особи. Проблемні питання стану дотримання захисту прав людини в Україні: зб. матеріалів IV Bсеукр. наук.-практ. конф. (м. Київ, 5 груд. 2013 р.). Ч. 1. С. 139-140; Загальнодержавна програма адаптації законодавства України до законодавства Європейського Союзу (Закон України від 18.03.2004 р. № 1629-IV). Відомості Верховної Ради Украӥни. 2004. № 29. Ст. 367; Стратегія наукових досліджень Національної академії правових наук України на 2016-2020 роки: затв. Постановою регіональних зборів Національної академії правових наук України від 03.03.2016 p. URL: http://www.aprnu.kharkiv.org/doc/ strategiya.pdf; Концепція Загальнодержавної програми адаптації законодавства України до законодавства Європейського Союзу: Закон України від 21.11.2002 p. № 228-15. Відомості Верховної Ради Украӥни. 2003. № 3. Ст. 12.

5 Про внесення змін до деяких законодавчих актів України щодо удосконалення законодавства 3 питань діяльності закладів охорони здоров’я: Закон України від 06.04.2017 р. № 2002-VIII. URL: http://zakon.rada.gov.ua/laws/show/2002-19.
} 
basis of a relevant license and professional activities of medical (pharmaceutical) employees. Depending on the form of ownership, health care institutions are formed and operate as public, municipal, private or mixed-form property.

\section{Constitutional and Criminal-Legal Grounds of Person's Health Care Protection in Ukraine}

The norms of criminal legislation play an important role in this system determining deeds, which are socially dangerous and criminal, and criminal punitive consequences. Taking into account the interrelation of these norms, they form a separate coordinated system - an independent criminal-legal institute, the basis of which are norms providing liability for deeds with their direct object being person's health. First of all, these are the crimes provided by Article 121 "Intentional grave physical injury", Article 122 "Intentional physical injury of middle gravity", Article 123 "Intentional grave or physical injury of middle gravity caused in a state of intense emotional distress", Article 124 "Intentional grave physical injury in excess of the boundaries of necessary defense or in case of exceeding the measures necessary for detention of a criminal", Article 125 "Intentional trivial physical injury", Article 126 "Blows and Torment", Article 126-1 "Domestic violence", Article 127 "Torture", Article 130 "Contamination with a human immunodeficiency virus or other incurable infectious disease" and Article 133 "Contamination with sexually transmitted disease" of the Criminal Code of Ukraine.

For example, Article 27 of the Constitution of Ukraine stipulates the provision according to which everyone has the right to protect their lives and health, life and health of other people from unlawful infringement. The criminal legal guarantee of this constitutional norm is the norm of the Criminal Code of Ukraine, enshrined in Article 124 "Intentional grave physical injury in excess of the boundaries of necessary defense or in case of exceeding the measures necessary for detention of a criminal" of the Criminal Code of Ukraine. Therefore, any person or other persons has the right to protect their health from unlawful violence, this may be carried out in case of necessary defense or emergency.

In addition, the Constitution of Ukraine protects a person and their health from crimes committed on specific grounds - racial, national, religious etc. In separate criminal-legal norms aimed at person's health 
protection, criminal liability is provided for crimes committed on the grounds of racial, national and religious intolerance (Part 2 of Article 121, Part 2 of Article 122, Part 2 of Article 126 and Part 2 of Article 127 of the Criminal Code of Ukraine). According to N. V. Uvarova, "under crimes against persons' life and health committed on grounds of racial, national or religious intolerance, it is proposed to understand socially dangerous, unlawful, guilty deeds against person's life and health committed by the subject of crime based on racial, national or religious intolerance" 6 . "Under actions aimed at incitement to national, racial or religious hatred and humiliation of national honor and dignity should be understood any action which purpose is to significantly increase the hostility of certain groups of population, a sense of enmity and disgust for other ethnicities or racial groups or religious denominations, humiliation of positive qualities of a particular nation in comparison with others" 7 .

These innovations in relation to crimes against person's health on grounds of racial, national and religious intolerance (2009) are reflected in the provisions of Article 24 and 35 of the Constitution of Ukraine. So, citizens have equal constitutional rights and freedoms and are equal before the law. There can be no privileges or restrictions based on race, skin color, political, religious or other beliefs, gender, ethnic or social origin, property status, place of residence, language or other grounds (Article 24). "Equality and impermissibility of a person's discrimination is not only constitutional principles of a national legal system of Ukraine, but also the fundamental values of the international community, as emphasized in international legal acts on the protection of human and civil rights and freedoms, in particular, in the International Covenant on Civil and Political Rights, 1966 (Articles 14, 26), the Convention for the Protection of Human Rights and Fundamental Freedoms (1950) (Article 14), Protocol № 12 to the Convention for the Protection of Human Rights and Fundamental Freedoms of 1950 (Article 1), ratified by Ukraine, and in the Universal Declaration of Human Rights 1948 (Articles 1, 2, 7)" ${ }^{\prime}$.

\footnotetext{
${ }^{6}$ Уварова Н. В. Кримінальна відповідальність за злочини проти життя та здоров'я особи, вчинені 3 мотивів расової, національної чи релігійної нетерпимості: дис. ... канд. юрид. наук. Дніпропетровськ, 2012. c. 51.

Науково-практичний коментар Кримінального кодексу України / за ред. М. І. Мельника, М. І. Хавронюка. 9-те вид., переробл. та доповн. Київ: Юридична думка, 2012. с. 444. http://zakon4.rada.gov.ua/.

Суду України 12.04.2012 p. № 9-рп/2012. URL:
} 
Article 35 of the Constitution of Ukraine stipulates that everyone has the right to freedom of thought and religion. This right includes the freedom to profess any religion or not to profess any, to freely arrange religious cults and ritual ceremonies individually or collectively, to conduct religious activities. "The exercise of this right may be limited by law only in the interests of protecting public order, health and morality of population or protecting the rights and freedoms of other people" 9 .

With the adoption of the Declaration on State Sovereignty and proclamation of the Act of Independence of Ukraine in 1991, Ukraine took a path of democratic society development. Adoption of the Constitution of Ukraine in 1996 is the evidence of this, in which the section "Rights, freedoms of a person and a citizen" includes personal rights, in particular, the right to respect for human dignity (Article 28 of the Constitution of Ukraine), namely, everyone has the right to respect to their dignity. No one shall be subjected to torture, cruel, inhuman or such that degrading their dignity, treatment or punishment. For the first time in the Ukrainian legislation an absolute ban of tortures was envisaged. In Article 127 of the Criminal Code of Ukraine of 2001 also provides for the crime of "tortures".

The ban of torture, cruel, inhuman or such that degrading their dignity, treatment or punishment is absolute and has no exceptions, and therefore does not allow violations during the war or other state of emergency stipulated in Article 64 of the Constitution of Ukraine. The constitutional rights and freedoms of a person and a citizen can not be limited except in cases stipulated by the Constitution of Ukraine. Under the conditions of a martial law or a state of emergency, certain restrictions of rights and freedoms may be established, indicating the term of validity of these restrictions. The rights and freedoms provided by Articles 24, 25, $27,28,29,40,47,51,52,55,56,57,59,60,61,62,63$ of this Constitution can not be limited ${ }^{10}$. This provision reveals the essence of one of the most complicated problems of realizing the protection of rights and freedoms of a person and a citizen - the problem of their restriction. The above interpretation of human rights proves the fact that they can not be restricted in any circumstances.

\footnotetext{
9 Конституція України: наук.-практ. комент. / Академія правових наук України. Харків: Право; Київ: Ін-Юре, 2003. с. 189.

${ }^{10}$ Конституція України: Закон від 28.06.1996 р. № 254к/96-ВР. Дата оновлення: 21.02.2019 p. URL: http://zakon2.rada.gov.ua/laws/show/254к/96-вр.
} 
In the context of the fundamental human right to life and health and other rights and freedoms (Part 1, Article 3 of the Constitution of Ukraine), determined by the natural human right, determine the content and orientation of the state activity. Due to the fact that one of the primary preconditions for human life activity is person's health, then, while protecting this right, the Ukrainian lawmaker approves these rights by consolidating them in the laws of Ukraine. The right of a person to legal protection of a person from contamination by a human immunodeficiency virus or other infectious disease and contamination with a sexually transmitted disease is not an exception that is provided by the Criminal Code of Ukraine in Article 130 "Contamination with a human immunodeficiency virus or other incurable infectious disease" and Article 133 "Contamination with sexually transmitted disease" 11.

Therefore, the provisions of the Constitution of Ukraine on protection of person's health from criminal infringement were reflected in the Criminal Code of Ukraine. In section II "Crimes against person's life and health", the Criminal Code of Ukraine distinguishes some institutions and the subject of our study is one of them - crimes against person's health. The lawmaker separates them into an individual institution depending on possible consequences, some of which are physical injury. The following degrees of physical injury are distinguished: grave, of middle gravity, and trivial physical injury. The basis for the gravity of physical injury is the dangerousness of damage to life, damage to health, and the duration of a health disorder. The following criteria for determining the gravity of physical injuries are also used: morbid anatomical (medical); economic and aesthetic.

Part 1 of Article 121 "Intentional grave physical injury" of the Criminal Code of Ukraine stipulates not only criminal liability for their commission, but also their features are determined: 1) dangerous to life at the time of commission; 2) causing the loss of any body or its functions; 3 ) mental illness; 4) lasting loss of working capacity not less than for one third; 5) abortion; 6) irrecoverable mutilation of face. In the disposition of Part 2 of this article one of possible consequences of intentional grave physical injury is provided, namely, death of a victim.

11 Катеринчук К. В. Вітчизняне законодавство про кримінальну відповідальність щодо охорони здоров’я особи: офіційне та неофіційне тлумачення. Наук. вісн. Ужгород. нац. ун-ту. 2013. № 4 (88). Ч. 2. Кн. 1. С. 43-46. 
Part 1 of Article 122 "Intentional physical injury of middle gravity" of the Criminal Code of Ukraine provides for criminal liability. The features of such physical injury are absence of danger to life and the consequences provided for in the disposition of Part 1 of Article 121 of the Criminal Code of Ukraine, but such that caused a lasting health disorder or a significant sustained loss of working capacity less than for one third. Article 125 of the Criminal Code of Ukraine specifies types of trivial physical injury, namely: trivial physical injury caused short-term health disorders or minor loss of working capacity (Part 2) and trivial physical injury, which did cause in these consequences (Part 1). Article 123 "Intentional grave or physical injury of middle gravity caused in a state of intense emotional distress" and Article 124 "Intentional grave physical injury in excess of the boundaries of necessary defense or in case of exceeding the measures necessary for detention of a criminal" of the Criminal Code of Ukraine provide for the privileged composition of crimes against person's health. The theory of criminal law has not used the term "privileged" for crimes against person's health, but it is widely used in crimes against person's life. In our opinion, it is advisable to apply it also to crimes against person's health, since the mitigation of criminal liability for this kind of physical injury is determined by the following circumstances: 1) person's socially dangerous deed provoked by an unlawful violence or a serious offense from the victim's side; 2) the subjective part of the crime composition is characterized by the emotional state of a subject (Article 123 of the Criminal Code of Ukraine); 3) in case of exceeding the limits of necessary defense (the limits of protection in a situation of emergency) and measures necessary for the detention of a criminal (Article 124 of the Criminal Code of Ukraine).

According to the structure peculiarities of the objective side, the crime against person's health has a material composition (Articles 121128, parts 2-4 of Article 130, Article 133 of the Criminal Code of Ukraine) and a formal composition (Article 121 of the Criminal Code of Ukraine in part - a danger to life at the moment of causing and part 1 of Article 130 of the Criminal Code of Ukraine).

According to the form of guilt, physical injury can be divided into intentional and committed through negligence. The intentional ones include crimes involving criminal liability for physical injury in Article 121 "Intentional grave physical injury", Article 122 "Intentional 
physical injury of middle gravity", Article 123 "Intentional grave or physical injury of middle gravity caused in a state of intense emotional distress", Article 124 "Intentional grave physical injury in excess of the boundaries of necessary defense or in case of exceeding the measures necessary for detention of a criminal", Article 125 "Intentional trivial physical injury" and Article 126-1 "Domestic violence" of the Criminal Code of Ukraine.

Through negligence, according to Article 128 of the Criminal Code of Ukraine, criminal liability appears in two cases only - these are grave and of middle gravity physical injury.

According to the consequences committed, the Criminal Code of Ukraine provides for: physical injuries, physical pain, severe physical pain and physical or moral suffering. According to V. M. Smitienko ${ }^{12}$, Article 130 "Contamination with a human immunodeficiency virus or other incurable infectious disease" and Article 133 "Contamination with sexually transmitted disease" of the Criminal Code of Ukraine are defined as "special kind" of physical injuries - contamination by certain types of dangerous infectious diseases.

\section{Classification of Crimes against Person's Health}

At the same time as a result of analysis of this issue it is possible to make a conclusion that there is no unified classification of crimes against person's health in Ukraine. Most of the scholars, having studied such issue, are giving more and more new suggestions on classification of crimes against person's health, justifying them in a different way. Since there is no a single point of view on this problem, we suggest studying all available teachings.

The Criminal Code of the USSR in 1922, 1927 and the Criminal Code of the USSR in $1960^{13}$ had a certain structural feature, in contrast to the Criminal Code of Ukraine in 2001. It was about the fact that a lawmaker, establishing liability for crimes against person's health, before the adoption of the Criminal Code of Ukraine in 2001, had placed a list of these and other elements of crimes in section III "Crimes against life, health, freedom and dignity of a person" exactly, thus strengthening the criminal-legal protection of a person. During the period of "evolution" of

\footnotetext{
12 Смитиенко В. Н. Уголовно-правовая охрана здоровья населения в СССР. Киев: Выща шк., Голов. изд-во, 1989. с. 125.

${ }^{13}$ У тексті підручника використано скорочені історичні назви країн.
} 
the Criminal Code on crimes against person's health, the features of physical injury were formulated more clearly, criminal liability for domestic violence, torture and placing of a person in danger of sexually transmitted disease was established.

The examination of a special literature on this topic on crimes against a person makes it possible to make a conclusion that the compositions of crimes in this category were divided by scientists into generic and direct objects. In the Criminal Code of the USSR, crimes against person's health were contained in one section together with crimes against life (which are available in the current $\mathrm{CC}$ of Ukraine), crimes against sexual freedom and sexual inviolability, crimes against personal freedom, honor and dignity. In this regard, their group belonging varies considerably from that proposed today, namely: in all cases, the name of the group of crimes against a person sometimes has a stylistic feature, or different scholars attributed this or that crime against person's health to different groups at different times.

For example, the scholars of the RSFSR and the USSR identified the following groups of crimes against a person: 1) crimes against life; 2) physical injury; 3) criminal deeds, dangerous for life and health; 4) sexual crimes; 5) crimes against personal freedom; 6) crimes against dignity of a person. The second group of crimes against a person included all kinds of physical injuries, intentional blows and hits, as well as contamination with sexually transmitted disease as a special type of physical injury. An article provided for criminal liability for intentional placing of another person in danger of contamination with sexually transmitted disease, according to Z. A. Vyshinska and A. A. Piontkovsky, belonged to a group of crimes that constitute a danger to life and health ${ }^{14}$. Later on, scholars attributed this crime to crimes against person's health, and this group of crimes was defined as crimes against person's health особи ${ }^{15}$, but not physical injury, as it was mentioned earlier.

During the next years, the division of crimes against a person, including the group of crimes against person's health, did not change, however, the following acts were criminalized by Decree of the Presidium

\footnotetext{
${ }^{14}$ Советское уголовное право: Часть особенная: учеб. для юрид. вузов // ВИЮН М-ва юстиции СССР. Москва: Госюриздат,1951. с. 176-209.

15 Советское уголовное право: Часть особенная: учеб. для юрид. вузов // Изд-во Моск. ун-та: Госюриздат, 1957. с. 182-199; Советское уголовное право: Часть особенная: учеб. для юрид. ин-тов. Ленинград, 1959. с. 140-167.
} 
of the Verkhovna Rada of the USSR "On Strengthening Responsibility for the Spreading of Sexually Transmitted Diseases" on October 1, 1971: contamination with sexually transmitted disease (Part 2 of Article 115), putting in danger of such contamination (Part 1 of Article 115) and avoidance of the treatment of sexually transmitted diseases (Article $115^{1}$ ). After changes made in the Criminal Code of Ukraine the scholars (M. D. Durmanov, O.V. Kuznetsov, S. V. Borodin, M. I. Bazhanov, V. V. Stashis, Yu. I. Liapunov) consider the crimes mentioned in the group of crimes against person's health ${ }^{16}$.

In the middle of the $90 \mathrm{~s}$, even before the adoption of the Criminal Code of Ukraine in 2001, N. V. Chernyshova, M. V. Volodko, and M. A. Khazin advocated the idea that the crimes of section III are divided into six groups. However, everyone proposed own peculiarity of article distribution to these groups. Thus, the second group, namely, crimes against health, included all kinds of physical injuries, blows, torment, contamination with sexually transmitted disease, avoidance of the treatment of a sexually transmitted disease, contamination with a human immunodeficiency virus, contamination with a human immunodeficiency virus by medical, pharmaceutical and employees in other fields ${ }^{17}$.

Later on, most scholars supported the position of their predecessors as for the division of crimes against a person into six groups. A special distinction was that the group - sexual crimes were renamed into crimes that infringe on sexual inviolability, and sexual freedom. Moreover, it was proposed to divide the crimes against health into three subgroups. The main (by the number of articles and real manifestations) subgroup was physical injuries. The second subgroup included such crimes as blows and torment. The third covered crimes, provided for a special type of harm to

\footnotetext{
16 Советское уголовное право: Часть особенная: учебник / В. Д. Меньшагин, В. Н. Кудрявцев, Б. А. Куринов и др.; под ред. В. Д. Меньшагина и др. М.: Изд-во МГУ, 1975. С. 166-168; Кузнецов А. В. Уголовное право и личность: монография. М.: Юрид. лит., 1977. С. 139; Советское уголовное право: Часть особенная: учебник / под ред. Г. А. Кригера, Б. А. Куринова, Ю. М. Ткачевского. М.: Изд-во МГУ, 1982. С. 139; Советское уголовное право: Часть особенная: : учебник. / С. В. Бородин, Ю. А. Воронин, Р. Р. Галиакбаров и др.; отв. ред. М. И. Ковалев. М.: Юрид. лит., 1983. С. 124; Уголовное право Украинской ССР на современном этапе. Часть Особенная / АН УССР. Ин-т гос. и права; А. Я. Светлов, М. И. Бажанов, В. В. Сташис и др.; отв. ред. А. Я. Светлов, В. В. Сташис. Киев: Наук. думка, 1985. С. 108-137; Советское уголовное право: Особенная часть: учебник. / Н. В. Васильев, М. А. Гельфер, П. И. Гришаев и др.; под ред. П. И. Гришаева, Б. В. Здравомыслова. М.: Юрид. лит.,1988. С. 161-172; Уголовное право УССР: Особенная часть: учебник / Ю. В. Александров и др. / под ред. М. И. Бажанова и др. Киев: Вища шк., 1989.С. 163-176.

${ }^{17}$ Кримінальне право України: тези лекцій і практ. завдання для курсантів Київ. училища міліції МВС України / Н. В. Чернишова, М. В. Володько, М. А. Хазін; за ред. В. М. Бовсуновського. Київ: Наук. думка, 1995. с. 263-282.
} 
health - contamination with a sexually transmitted disease and human immunodeficiency virus. These are crimes such as contamination with a sexually transmitted disease, avoidance of the treatment of a sexually transmitted disease, contamination with human immunodeficiency virus, contamination with a human immunodeficiency virus by medical, pharmaceutical and employees of other fields, disclosure of information about medical examination for human immunodeficiency virus contamination and its consequences. Scientists note that these articles, by their characteristics, are such that they put in danger person's life and health, and avoidance of the treatment of a sexually transmitted disease, contamination with the human immunodeficiency virus affects person's dignity ${ }^{18}$.

Other scientists distinguish crimes against personal safety in a separate group, namely: conscious putting in danger of contamination with a sexually transmitted disease, avoidance of the treatment of a sexually transmitted disease, contamination with a human immunodeficiency virus, avoidance of the treatment of sexually transmitted disease and contamination with a human immunodeficiency virus ${ }^{19}$.

The classification of crimes by groups changed with the adoption of the Criminal Code of Ukraine in 2001. Due to the fact that a national lawmaker changed the Code structurally, distinguishing crimes against person's life and health in a separate section II, the issue of classification of crimes against person's health remained relevant at the same time. Thus, the crimes against person's health (M. I. Bazhanov, V. V. Stashis, O. S. Sotula, N. O. Guturova, V. I. Kasyniuk, V. O. Glushkov) include such crimes of the current Criminal Code of Ukraine: various types of physical injuries (Articles 121-125, 128), blows and torment (Article 126), tortures (Article 127), special types of physical injury: contamination with human immunodeficiency virus or other incurable infectious disease (Art. 130), contamination with a sexually transmitted disease (Article 133) ${ }^{20}$.

\footnotetext{
18 Кримінальне право України. Особлива частина: підручник / Ю. В. Александров, В. І. Антипов, М. В. Володько та ін.; відп. ред. В. І. Шакун. Київ: Правові джерела, 1998. с. 153

19 Кримінальне право України. Особлива частина: підручник / Г. В. Андрусів та ін.; за ред. П. С. Матишевського та ін.; Київ. нац. ун-т імені Тараса Шевченка. Юридичний фак. 2 вид. Київ: Юрінком Інтер, 1999. с. 185-204.

20 Велика українська юридична енциклопедія: у 20 т. Харків: Право, 2016. Т. 17: Кримінальне право / редкол.: В. Я. Тацій (голова), В. І. Борисов (заст. голови) та ін.; Нац. акад. прав. наук України; Ін-т держави і права ім. В. М. Корецького НАН України; Нац. юрид. ун-т ім. Ярослава Мудрого. 2017. с. 317-318; Кримінальне право України. Загальна та Особлива частини: навч. посіб. / В. М. Стратонов,
} 
O. A. Chuvakov proposes to supplement this classification of crimes against person's health by Article 145 (Illegal disclosure of medical secrets) to the Criminal Code of Ukraine ${ }^{21}$. According to S. I. Seletsky, the crimes against person's health include all kinds of physical injuries, blows and torment, torture, a threat of murder, leaving in danger, not providing assistance to a person in a state of danger to life $\mathrm{e}^{2}$.

Detailed analysis of the composition features of crimes provided by Articles 121-145 of the Criminal Code of Ukraine (first of all, generic and direct objects of composition of crimes, forms of guilt, the nature of criminal consequences), proves that these crimes are diverse and not always directly and immediately infringe on the victim's health. G. E. Boldar, V. O. Hatseliuk and Yu. O. Kucher propose these norms to be united into groups:

1) Crimes that cause damage to person's health (Article 121-129 of the Criminal Code of Ukraine);

2) Crimes that cause harm to person's health, committed in the field of protection of person's life and health, from certain types of dangerous infectious diseases (Articles 130;131; 133 of the Criminal Code of Ukraine);

3) Crimes that cause damage to person's health committed in the field of provision of medical services (Article 134; 138-144 of the Criminal Code of Ukraine);

4) Crimes that cause damage to person's health as a result of leaving the person without assistance or as a result of guilty person improper execution of their duties (Article 135-137 of the Criminal Code of Ukraine);

5) Crimes in the field of health protection related to the unlawful dissemination of medical secrets (Article 132; 145 of the Criminal Code of Ukraine $)^{23}$.

О. С. Сотула; заг. ред. В. М. Стратонов; Херсон. держ. ун-т. Київ: Істина, 2007. с. 187; Кримінальне право України. Особлива частина: підручник / Ю. В. Александров та ін.; ред. М. І. Мельник, В. А. Клименко. 3-тє вид., перероб. і допов. Київ: Атіка, 2009. с. 47; Кримінальне право України. Особлива частина: підручник / Ю. В. Баулін та ін.; за ред. В. В. Сташиса, В. Я. Тація. 4 вид., перероб. і допов. Харків: Право, 2010. с. 47-60; Уголовное право Украины. Особенная часть: учебник / М. И. Бажанов др.; под ред. М. И. Бажанова; Нац. юрид. акад. Украины им. Ярослава Мудрого. Киев: Юринком Интер, 2003. с. 49.

${ }^{21}$ Кримінальне право України: Особлива частина: підручник / за заг. ред. д-ра юрид. наук, проф., засл. діяча науки і техніки України С. Л. Стрельцова. Харків: Одіссей, 2009. с. 42.

${ }^{22}$ Селецький С. І. Кримінальне право України. Особлива частина: навч. посіб. Київ: Центр учбової літ., 2012. с. 28.

${ }^{23}$ Кримінальне право. Особлива частина: підручник / за ред. О. О. Дудорова, Є. О. Письменського. 2 вид. Київ: «ВД «Дакор», 2013. с. 66-67. 
O. M. Dzhuzha and A. V. Savchenko offer the following classification of crimes against person's health:

1) Crimes against person's health (Articles 121-128; 130; 133 of the Criminal Code of Ukraine);

1.1) Physical injury (Articles 121-125; 128 of the Criminal Code of Ukraine);

1.2) Causing physical or moral suffering (Article 126; 127 of the Criminal Code of Ukraine);

1.3) Contamination with social diseases (Article 130; 133 of the Criminal Code of Ukraine) ${ }^{24}$.

E. V. Kornienko includes in crimes against health such deeds that do not harm the health directly, but put it in danger, namely: a threat of murder (Article 129 of the Criminal Code of Ukraine); carrying out an abortion by a person who does not have special medical education (Part 1 of Article 134 of the Criminal Code of Ukraine); conscious putting another person in danger of contamination with a human immunodeficiency virus or other incurable infectious disease that is dangerous to human life (Part 1 of Article 130 of the Criminal Code of Ukraine $)^{25}$. Somewhat different classification was proposed by V. O. Gatseliuk. In his opinion, the crimes against person's health include: 1) physical injury (Articles $121-125 ; 128) ; 2$ ) causing physical or moral suffering (Articles 126, 127, 129); 3) contamination with special diseases (Articles 130-131) ${ }^{26}$. The classification given above for crime compositions against person's health leads to a number of questions. Firstly, the crime, for which liability is provided in Article 131 "Improper performance of professional duties caused contamination of the person by a human immunodeficiency virus or other incurable infectious disease" is indicated in the group "contamination with special diseases" and then duplicated in "crimes in the medical field". Secondly, the crime, for which liability is stipulated in Article 133 "Contamination with sexually transmitted disease" is not mentioned at all, and the group, which includes

\footnotetext{
${ }^{24}$ Кваліфікація злочинів, підслідних органам внутрішніх справ: навч. посіб. / В. В. Коваленко, О. М. Джужа, А. В. Савченко, В. В. Кузнецов та ін.; за заг. ред. В. В. Коваленка; за наук. ред. О. М. Джужи, А. В. Савченка. Київ: Атіка, 2011. с. 9.

${ }_{25}$ Корнієнко Є. В. Кримінально-правова характеристика зараження вірусом імунодефіциту людини чи іншої невиліковної інфекційної хвороби: дис. ... канд. юрид. наук. Київ, 2013. с. 73.

${ }^{26}$ Гацелюк В. О. Щодо класифікації злочинів проти здоров’я у КК України 2001 року. Проблеми застосування, удосконалення та подальшої гармонізації із законодавством європейських краӥн: матеріали міжнар. наук.-практ. конф. 10 років чинності Кримінального кодексу України (м. Харків, 13-14 жовт. 2011 р.) / редкол.: В. Я. Тацій (голов. ред.), В. І. Борисов (заст. голов. ред.) та ін. Харків: Право, 2011. С. 394-400.
} 
crimes, for which liability is stipulated in Article 126 "Blows and torment" and Article 127 "Torture" belong to a group of crimes against person's health causing physical or moral suffering. Unfortunately, the author of this classification V. O. Gatseliuk does not indicate one of the consequences - physical pain, which is a compulsory feature of these compositions of crimes. In addition, Article 129 of the Criminal Code of Ukraine "A threat of murder", in our opinion, can not be included in this subgroup, since this crime has another direct object. According to Ye.V. Fesenko, the crimes against person's health in relation to the specific object are divided into: 1) crimes against person's physical inviolability - this is a physical injury of varying degrees of gravity, blows and torment, as well as torture; 2) crimes against personal safety: a) general types of crimes against personal safety (Articles 129-136); b) crimes against personal safety, connected with violations of the established procedure for the performance of certain activities and the fulfillment of respective responsibilities (Articles 137-144, etc.) ${ }^{27}$.

Therefore, according to the above-mentioned classification of crimes against person's life and health of section II of the Criminal Code of Ukraine, the opinion was established that the crimes against person's health include all types of physical injury (Articles 121-125, 128 of the Criminal Code of Ukraine), blows and torment (Article 126 of the Criminal Code of Ukraine), domestic violence (Article 126-1), torture (Article 127 of the Criminal Code of Ukraine), contamination with a human immunodeficiency virus or other incurable infectious disease (Article 130 of the Criminal Code of Ukraine) and contamination with a sexually transmitted disease (Article 133 of the Criminal Code of Ukraine $)^{28}$.

\section{CONCLUSIONS}

One of the priorities of our state, defined in Article 3 of the Constitution of Ukraine, is the protection of person's life and health. Since the independence of Ukraine, the concept of "the state exists for a person" has worked, namely, active steps are taken to ensure the protection of natural human rights - life and health. In order to effectively solve such

\footnotetext{
27 Фесенко С. В. Проблеми систематизації статей КК щодо відповідальності за злочини проти здоров'я особи та населення. Кримінально-правова охорона життя та здоров'я особи: матеріали наук.практ. конф. (м. Харків, 22-23 квіт. 2004 р.) / редкол.: Сташис В. В. (голов. ред.) та ін. Київ - Харків: «Юринком Інтер», 2004. С. 137-140.

28 Катеринчук Е.В. Классификация преступлений против здоровья человека. Современный научный вестник. 2014. № 44 (240). С. 42-50.
} 
problems, the state must protect, make safe society against unlawful infringements on person's life and health. In this regard, the effective development of means aimed at protecting these benefits and an effective set of measures aimed at systematic counteraction to crimes against person's health are fundamental issues. The legal norms that form section II of the Special Part of the Criminal Code of Ukraine - crimes against persons' life and health and comply with the provisions of the Constitution of Ukraine have one of the key places.

Studying the features of classification of crimes against person's health, it was established that the scientists attributed these crimes to different groups in different periods of national legislation development. This feature is caused by the fact that these crimes were placed in other sections (chapters) by the lawmaker. At present, we include in the crimes against person's health all types of physical injuries (Articles 121-125, 128 of the Criminal Code of Ukraine), blows and torment (Article 126 of the Criminal Code of Ukraine), domestic violence (Article 126-1), torture (Article 127 of the Criminal Code of Ukraine), contamination by a human immunodeficiency virus or other incurable infectious disease (Article 130 of the Criminal Code of Ukraine) and contamination with a sexually transmitted disease (Article 133 of the Criminal Code of Ukraine).

\section{SUMMARY}

The analysis of constitutional norms in relation to person's health is carried out. It is determined that person's health protection is regulated by the Fundamentals of the Ukrainian legislation on health care as well as other norms of Ukrainian legislation on health care protection. It is proved that constitutional provisions on person's health protection are reflected in full in prohibitive norms of the Criminal Code of Ukraine.

The scope of criminal infringements in the field of person's health protection is outlined. It was emphasized that division of these crimes into groups is carried out depending on their structural placement in the Criminal Code of Ukraine in 2001 according to the generic object. The following groups of crimes are distinguished: 1) crimes against life; 2) crimes against person's health including all types of physical injuries (Articles 121-125, 128 of the Criminal Code of Ukraine), blows and torment (Article 126 of the Criminal Code of Ukraine), domestic violence (Article 126-1), torture (Article 127 of the Criminal Code of Ukraine), contamination by a human immunodeficiency virus or other incurable infectious disease (Article 130 of the Criminal Code of Ukraine) and 
contamination with a sexually transmitted disease (Article 133 of the Criminal Code of Ukraine); 3) crimes putting in danger person's life and health.

\section{REFERENCES}

1. Конституція України: Закон від 28.06.1996 р. № 254к/96-ВР. Дата оновлення: 21.02.2019 p. URL: http://zakon2.rada.gov.ua/laws/ show/254к/96-вр.

2. Кримінальний кодекс України: Закон від 05.04.2001 р. № 2341III. Дата оновлення: 26.02.2019 p. URL: http://zakon4.rada.gov.ua/laws/ show/2341-14.

3. Основи законодавства України про охорону здоров'я: Закон України від 19.11.1992 р. № 2801-XII. Дата оновлення 01.01.2019 р. URL: http://zakon5.rada.gov.ua/laws/show/2801-12.

4. Катеринчук К. В. Державні програми, як основа запобігання злочинних посягань на здоров'я особи. Проблемні питання стану дотримання захисту прав людини в Україні: зб. матеріалів IV Всеукр. наук.-практ. конф. (м. Київ, 5 груд. 2013 р.). Ч. 1. С. 139-140.

5. Загальнодержавна програма адаптації законодавства України до законодавства Європейського Союзу (Закон України від 18.03.2004 р. № 1629-IV). Відомості Верховної Ради Украӥни. 2004. № 29. Ст. 367.

6. Стратегія наукових досліджень Національної академії правових наук України на 2016-2020 роки: затв. Постановою регіональних зборів Національної академії правових наук України від 03.03.2016 p. URL: http://www.aprnu.kharkiv.org/doc/strategiya.pdf.

7. Концепція Загальнодержавної програми адаптації законодавства України до законодавства Європейського Союзу: Закон України від 21.11.2002 р. № 228-15. Відомості Верховної Ради України. 2003. № 3. Ст. 12.

8. Про внесення змін до деяких законодавчих актів України щодо удосконалення законодавства 3 питань діяльності закладів охорони здоров’я: Закон України від 06.04.2017 р. № 2002-VIII. URL: http://zakon.rada.gov.ua/laws/show/2002-19.

9. Уварова Н. В. Кримінальна відповідальність за злочини проти життя та здоров'я особи, вчинені з мотивів расової, національної чи релігійної нетерпимості: дис. ... канд. юрид. наук. Дніпропетровськ, 2012. 213 c. 
10. Науково-практичний коментар Кримінального кодексу України / за ред. М. І. Мельника, М. І. Хавронюка. 9-те вид., переробл. та доповн. Київ: Юридична думка, 2012. 1316 с.

11. Рішення Конституційного Суду України 12.04 .2012 p. № 9-рп/2012. URL: http://zakon4.rada.gov.ua/.

12. Конституція України: наук.-практ. комент. / Академія правових наук України. Харків: Право; Київ: Ін-Юре, 2003. 808 с.

13. Катеринчук К. В. Вітчизняне законодавство про кримінальну відповідальність щодо охорони здоров'я особи: офіційне та неофіційне тлумачення. Наук. вісн. Ужсгород. нац. ун-ту. 2013. № 4 (88). Ч. 2. Кн. 1. С. 43-46.

14. Смитиенко В. Н. Уголовно-правовая охрана здоровья населения в СССР. Киев: Выща шк., Голов. изд-во, 1989. 243 с.

15. Советское уголовное право: Часть особенная: учеб. для юрид. вузов // ВИЮН М-ва юстиции СССР. Москва: Госюриздат,1951. 431 с.

16. Советское уголовное право: Часть особенная: учеб. для юрид. вузов // Изд-во Моск. ун-та: Госюриздат,1957. 542 с.

17. Советское уголовное право: Часть особенная: учеб. для юрид. ин-тов. Ленинград, 1959. 470 с.

18. Советское уголовное право: Часть особенная: учебник / В. Д. Меньшагин, В. Н. Кудрявцев, Б. А. Куринов и др.; под ред. В. Д. Меньшагина и др. М.: Изд-во МГУ, 1975. 487 с.

19. Кузнецов А. В. Уголовное право и личность: монография. М.: Юрид. лит., 1977. 168 с.

20. Советское уголовное право: Часть особенная: учебник / под ред. Г. А. Кригера, Б. А. Куринова, Ю. М. Ткачевского. М.: Изд-во МГУ, 1982. $471 \mathrm{c}$.

21. Советское уголовное право: Часть особенная: : учебник. / С. В. Бородин, Ю. А. Воронин, Р. Р. Галиакбаров и др.; отв. ред. М. И. Ковалев. М.: Юрид. лит., 1983. 479 с.

22. Уголовное право Украинской ССР на современном этапе. Часть Особенная / АН УССР. Ин-т гос. и права; А. Я. Светлов, М. И. Бажанов, В. В. Сташис и др.; отв. ред. А. Я. Светлов, В. В. Сташис. Киев: Наук. думка, 1985. 448 с.

23. Советское уголовное право: Особенная часть: учебник. / Н. В. Васильев, М. А. Гельфер, П. И. Гришаев и др.; под ред. П. И. Гришаева, Б. В. Здравомыслова. М.: Юрид. лит.,1988. 608 с. 
24. Уголовное право УССР: Особенная часть: учебник / Ю. В. Александров и др. / под ред. М. И. Бажанова и др. Киев: Вища шк., 1989. 503 с.

25. Кримінальне право України: тези лекцій і практ. завдання для курсантів Київ. училища міліції МВС України / Н. В. Чернишова, М. В. Володько, М. А. Хазін; за ред. В. М. Бовсуновського. Київ: Наук. думка, 1995. 455 с.

26. Кримінальне право України. Особлива частина: підручник / Ю. В. Александров, В. І. Антипов, М. В. Володько та ін.; відп. ред. В. І. Шакун. Київ: Правові джерела, 1998. 894 с.

27. Кримінальне право України. Особлива частина: підручник / Г. В. Андрусів та ін.; за ред. П. С. Матишевського та ін.; Київ. нац. ун-т імені Тараса Шевченка. Юридичний фак. 2 вид. Київ: Юрінком Інтер, 1999. $891 \mathrm{c}$.

28. Велика українська юридична енциклопедія: у 20 т. Харків: Право, 2016. Т. 17: Кримінальне право / редкол.: В. Я. Тацій (голова), В. І. Борисов (заст. голови) та ін.; Нац. акад. прав. наук України; Ін-т держави і права ім. В. М. Корецького НАН України; Нац. юрид. ун-т ім. Ярослава Мудрого. 2017. 1064 с.

29. Кримінальне право України. Загальна та Особлива частини: навч. посіб. / В. М. Стратонов, О. С. Сотула; заг. ред. В. М. Стратонов; Херсон. держ. ун-т. Київ: Істина, 2007. 400 с.

30. Кримінальне право України. Особлива частина: підручник / Ю. В. Александров та ін.; ред. М. І. Мельник, В. А. Клименко. 3-тє вид., перероб. і допов. Київ: Атіка, 2009. 744 с.

31. Кримінальне право України. Особлива частина: підручник / Ю. В. Баулін та ін.; за ред. В. В. Сташиса, В. Я. Тація. 4 вид., перероб. і допов. Харків: Право, 2010. 608 с.

32. Уголовное право Украины. Особенная часть: учебник / М. И. Бажанов др.; под ред. М. И. Бажанова; Нац. юрид. акад. Украины им. Ярослава Мудрого. Киев: Юринком Интер, 2003. 511 с.

33. Кримінальне право України: Особлива частина: підручник / за заг. ред. д-ра юрид. наук, проф., засл. діяча науки і техніки України С. Л. Стрельцова. Харків: Одіссей, 2009. 344 с.

34. Селецький С. I. Кримінальне право України. Особлива частина: навч. посіб. Київ: Центр учбової літ., 2012. 330 с.

35. Кримінальне право. Особлива частина: підручник / за ред. О. О. Дудорова, Є. О. Письменського. 2 вид. Київ: «ВД «Дакор», 2013. $786 \mathrm{c.}$ 
36. Кваліфікація злочинів, підслідних органам внутрішніх справ: навч. посіб. / В. В. Коваленко, О.М. Джужа, А. В. Савченко, В. В. Кузнецов та ін.; за заг. ред. В. В. Коваленка; за наук. ред. О. М. Джужи, А. В. Савченка. Київ: Атіка, 2011. 648 с.

37. Корнієнко Є. В. Кримінально-правова характеристика зараження вірусом імунодефіциту людини чи іншої невиліковної інфекційної хвороби: дис. ... канд. юрид. наук. Київ, 2013. 249 с.

38. Гацелюк В. О. Щодо класифікації злочинів проти здоров'я у КК України 2001 року. Проблеми застосування, удосконалення та подальшої гармонізаиії із законодавством європейських країн: матеріали міжнар. наук.-практ. конф. 10 років чинності Кримінального кодексу України (м. Харків, 13-14 жовт. 2011 р.) / редкол.: В. Я. Тацій (голов. ред.), В. І. Борисов (заст. голов. ред.) та ін. Харків: Право, 2011. С. 394-400.

39. Фесенко С. В. Проблеми систематизації статей КК щодо відповідальності за злочини проти здоров'я особи та населення. Кримінально-правова охорона життя та здоров'я особи: матеріали наук.-практ. конф. (м. Харків, 22-23 квіт. 2004 р.) / редкол.: Сташис В. В. (голов. ред.) та ін. Київ - Харків: «Юринком Інтер», 2004. C. 137-140.

40. Катеринчук Е. В. Классификация преступлений против здоровья человека. Современный научный вестник. 2014. № 44 (240). C. $42-50$.

\section{Information about the author:} Katerynchuk K. V.

Candidate of Juridical Sciences, Assistant Professor at the Department of Special Legal Disciplines of the Educational-Scientific Humanitarian Institute of the V. I. Vernadsky Taurida National University

33, Ivana Kudri str., Kyiv, Ukraine 